

\section{State Clean Energy Practices: Renewable Energy Rebates}

\section{Eric Lantz and Elizabeth Doris}

Prepared under Task No. IGST.8300

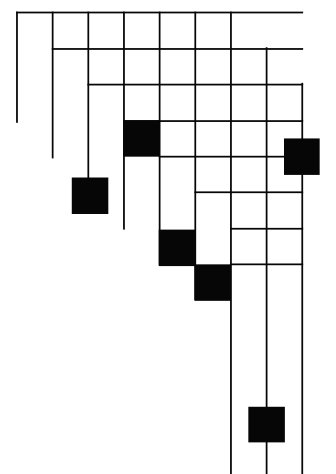




\section{NOTICE}

This report was prepared as an account of work sponsored by an agency of the United States government. Neither the United States government nor any agency thereof, nor any of their employees, makes any warranty, express or implied, or assumes any legal liability or responsibility for the accuracy, completeness, or usefulness of any information, apparatus, product, or process disclosed, or represents that its use would not infringe privately owned rights. Reference herein to any specific commercial product, process, or service by trade name, trademark, manufacturer, or otherwise does not necessarily constitute or imply its endorsement, recommendation, or favoring by the United States government or any agency thereof. The views and opinions of authors expressed herein do not necessarily state or reflect those of the United States government or any agency thereof.

Available electronically at http://www.osti.gov/bridge

Available for a processing fee to U.S. Department of Energy and its contractors, in paper, from:

U.S. Department of Energy

Office of Scientific and Technical Information

P.O. Box 62

Oak Ridge, TN 37831-0062

phone: 865.576 .8401

fax: 865.576 .5728

email: mailto:reports@adonis.osti.gov

Available for sale to the public, in paper, from:

U.S. Department of Commerce

National Technical Information Service

5285 Port Royal Road

Springfield, VA 22161

phone: 800.553.6847

fax: 703.605.6900

email: orders@ntis.fedworld.gov

online ordering: http://www.ntis.gov/ordering.htm 


\section{Acknowledgments}

The authors would like to thank Katrina Pielli and her colleagues from the Environmental Protection Agency's Clean Energy Program for review of an early draft of this paper. In addition, we would like to thank NREL reviewers Ron Benioff and Toby Couture for their valuable feedback and comments. Finally, thanks go to Jennifer Josey with NREL's Technical Communications Office for her editing assistance. 


\section{List of Acronyms}

$\begin{array}{ll}\text { AAGR } & \text { Average annual growth rate } \\ \text { AWEA } & \text { American Wind Energy Association } \\ \text { CEC } & \text { California Energy Commission } \\ \text { CFL } & \text { Compact fluorescent light bulb } \\ \text { CORE } & \text { Customer on-site renewable energy } \\ \text { CSI } & \text { California Solar Initiative } \\ \text { DOE } & \text { Department of Energy } \\ \text { DSIRE } & \text { Database of State Incentives for Renewable Energy } \\ \text { EPBI } & \text { Expected performance-based incentive } \\ \text { ERP } & \text { Emerging Renewables Program } \\ \text { ETO } & \text { Energy Trust of Oregon } \\ \text { FIT } & \text { Feed-in tariff } \\ \text { HECO } & \text { Hawaiian Electric Company } \\ \text { ITC } & \text { Investment Tax Credit } \\ \text { MW } & \text { Megawatts } \\ \text { NREL } & \text { National Renewable Energy Laboratory } \\ \text { PBI } & \text { Production-based incentive } \\ \text { PV } & \text { Photovoltaic } \\ \text { R\&D } & \text { Research and development } \\ \text { RE } & \text { Renewable energy } \\ \text { REC } & \text { Renewable energy credit } \\ \text { SCEPA } & \text { State clean energy policies analysis } \\ \text { SREC } & \text { Solar renewable energy credit } \\ & \end{array}$




\section{Executive Summary}

Rebates are a classic marketing tool and have been widely used for various consumer goods. A successful renewable energy rebate program may reduce technology costs, demonstrate technological feasibility, reveal potential market barriers, and/or increase market penetration of renewable energy technologies. As such, rebate programs for renewable energy have achieved widespread popularity.

This report functions as a primer for renewable energy rebate programs. It highlights the impacts of specific renewable energy rebate programs on renewable energy markets around the country, as well as rebate program impacts on overarching energy policy drivers. It also discusses lessons learned, challenges, ideal applications, keys to success, and complementary and alternative policies.

Results indicate that rebate programs can have a strong deployment impact on emerging renewable energy markets. Furthermore, any production from new clean energy resources increases energy sector diversity and makes a direct contribution to broader environmental policy goals. New industries also generate jobs and economic output. However, because rebate programs typically target emerging industries that start with little or zero market share, they lack the scale necessary to make a large contribution to overarching clean energy goals. Nevertheless, the market initiating attributes of renewable energy rebates makes them a critical first step in the deployment and diffusion process.

Rebates function well when applied to market-ready technologies that are prepared to move a technology from the prototype stage to mass production. In addition, they function well when they are matched with a clear set of goals that apply their market initiating strengths. Rebate programs may function poorly when context-specific market factors are not considered or when the precise rebate amount is not tailored to existing market and policy conditions.

Rebate programs may be most effective when designed and implemented as one component in a suite of policies. Rebates can be applied to jumpstart or rapidly expand a specific renewable energy technology market while additional complementary policy measures may be put in place to drive larger scale shifts in energy production. 


\section{Table of Contents}

List of Figures............................................................................................................................ viii

List of Tables ................................................................................................................................... vii

SCEPA Project Background............................................................................................................... 1

Introduction..................................................................................................................................... 1

Rebate Program Prevalence............................................................................................................. 3

Overview of Renewable Energy Market Activity with Rebates ..................................................... 4

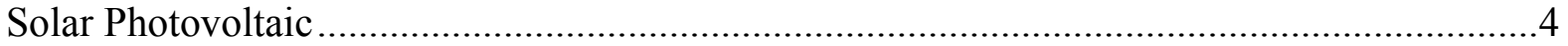

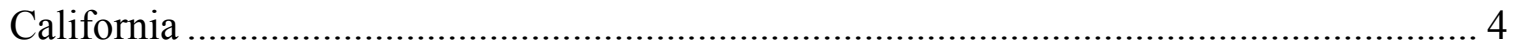

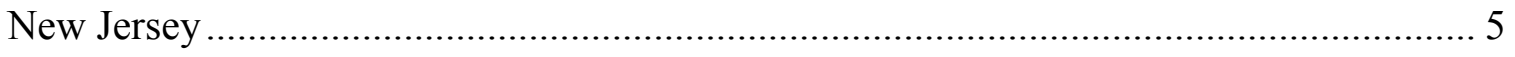

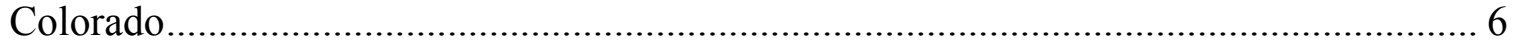

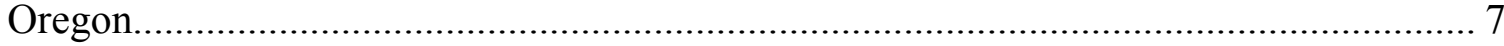

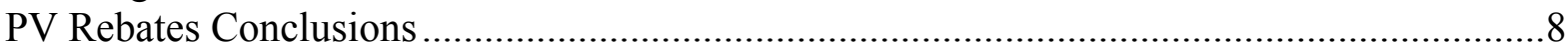

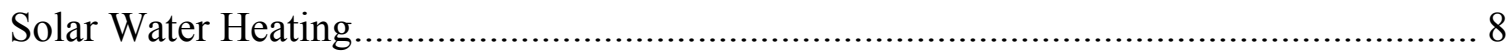

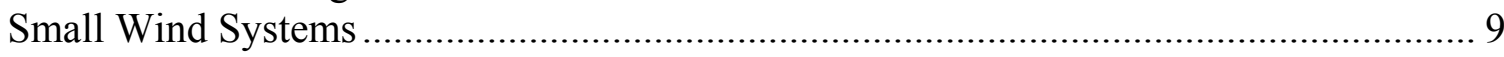

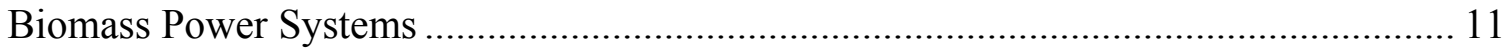

Rebate Programs and Market Activity: General Conclusions..................................................... 12

Impacts on Renewable Energy Policy Drivers .............................................................................. 13

Challenges Associated with Rebate Programs ...................................................................................... 18

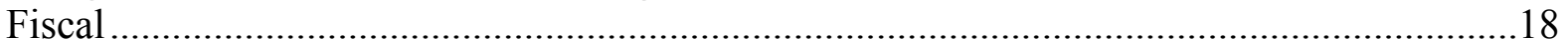

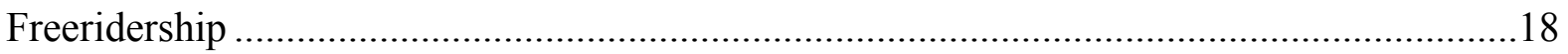

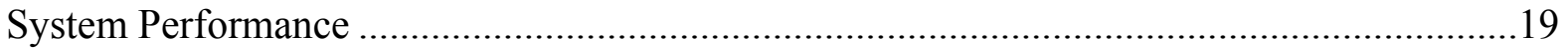

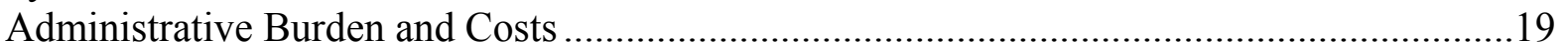

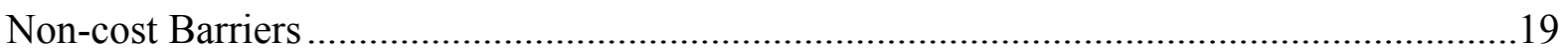

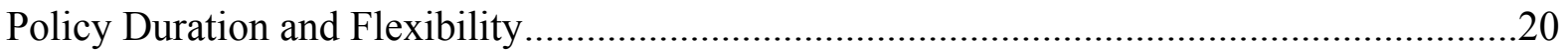

Ideal Conditions and Applications ......................................................................................... 21

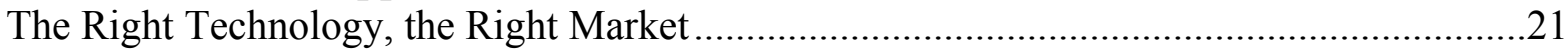

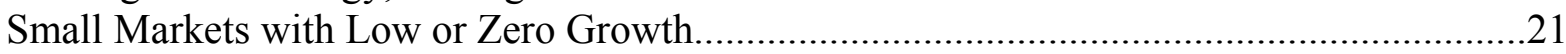

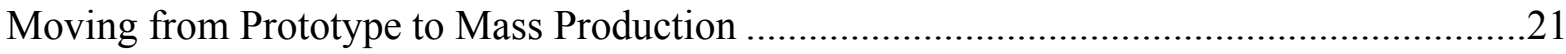

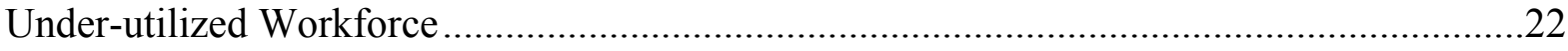

High-value Markets with Supporting Technical Policy.........................................................22

Key Elements of a Successful Program....................................................................................... 23

Policy Complements and Alternatives .......................................................................................... 24

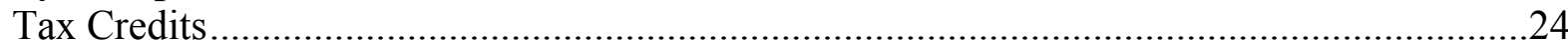

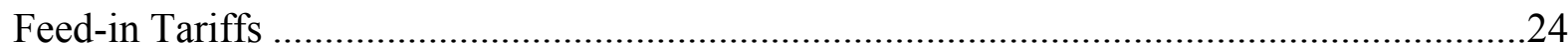

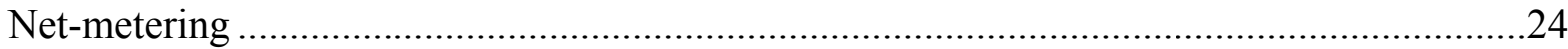

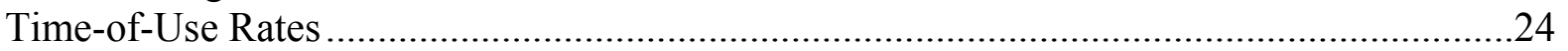

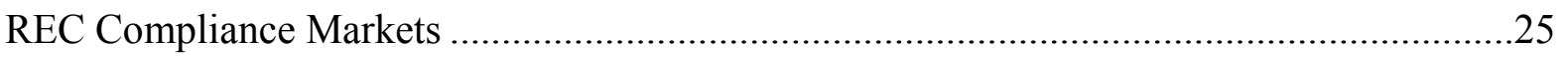

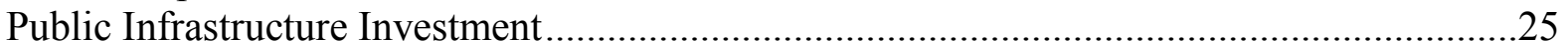

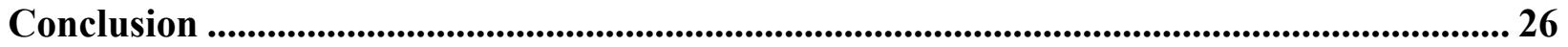

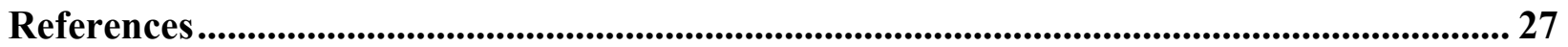




\section{List of Figures}

Figure 1. Annual PV market and average rebate paid $(\$ / \mathrm{kW})$ in the grid connected

California market..................................................................................... 5

Figure 2. Annual PV installations supported by New Jersey's CORE rebate program..... 6

Figure 3. Market impacts by annual PV system installations and rebate value................ 7

Figure 4. PV market impacts in the commercial and residential sector as a result of ETO

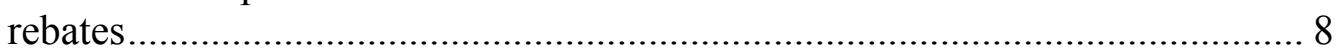

Figure 5. Small wind turbine installations by year and average rebate $(\$ / \mathrm{kW}) \ldots \ldots \ldots \ldots . . . .10$

\section{List of Tables}

Table 1. State Level Biopower Program Results.................................................... 11

Table 2. Rebate Program Impacts on High-level Clean Energy Policy Drivers ............ 14

Table 3. State Solar Rebate Program Installed Project Average Annual Growth Rate

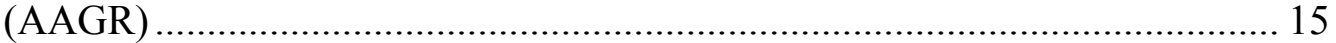

Table 4. Short-term Energy Security Impact: Estimated Annual Energy Production from Capacity Installed under State Rebate Programs*

Table 5. Short-term Economic Development: Modeled Solar Industry Economic Development Impacts from Capacity Installed under State Rebate Programs. 16

Table 6. Environmental Impacts: Estimated Emissions Reductions from Capacity Installed under State Rebate Programs 


\section{SCEPA Project Background}

The State Clean Energy Policies Analysis (SCEPA) project is supported by the Weatherization and Intergovernmental Program within the Department of Energy's (DOE) Office of Energy Efficiency and Renewable Energy. This project seeks to quantify the impacts of existing state policies, and to identify crucial policy attributes and their potential applicability to other states. The goal is to help states determine which clean energy policies or policy portfolios will best accomplish their environmental, economic, and security goals. Analysts from the National Renewable Energy Laboratory (NREL) are implementing this work, with state officials and policy experts providing input and review. This report focuses on renewable energy rebate programs.

For more information on the SCEPA project, access NREL's Applying Technologies Web site at http://www.nrel.gov/applying technologies/scepa.html.

\section{Introduction}

Rebates are classic marketing tools that have been widely used for various consumer goods and can be implemented by manufacturers, governments, utilities, or private firms. Mechanisms for administering and collecting rebates vary nearly as much as individual rebate programs; however, rebates generally provide a lower cost good via some direct cash mechanism. ${ }^{1}$ The rationale for implementing a rebate program varies but may include greater market penetration, cost reductions via economies of scale, consumer information acquisition, or better tracking of sales and use.

Renewable energy rebates, also known as buy-down programs, provide a refund or discount off the cost of new renewable energy installations. Programs are often administered through local utilities or state agencies, and rebates are generally acquired through an application process. Rebate payments vary and are often based on the installed capacity of a system with the rebate value set at a given rate (i.e., dollars per watt). Rebate payments may be limited by size or dollar value, and/or include a one-time payment for renewable energy credits (RECs). They may also be coupled with production or expected production-based incentive (PBI) payments. ${ }^{2}$

A primary driver of renewable energy rebate programs is the desire to stimulate early market growth for emerging technologies. By stimulating early stage market growth, cost reductions may be achieved by economies of scale or the elimination of supply chain

\footnotetext{
${ }^{1}$ The direct cash aspect of a rebate is generally more valuable than a similar functioning non-cash incentive. Non-cash incentives include tax credits which may lower the cost of specific good but require a tax appetite, and in some cases are only collected at the time of filing a tax return. As a result, a tax credit is not of the same value as a direct cash rebate or a simple discount off of the retail price.

${ }^{2}$ Production-based payments provide an incentive for the renewable energy system to be installed and maintained with maximum energy production in mind (Barbose 2006). Another mechanism that attempts to incorporate the value of a $\mathrm{PBI}$ as well as the ability to provide an upfront cost reduction similar to a rebate program is an expected performance-based incentive (EPBI). An EPBI provides an upfront payment based on the modeled performance results of the system. EPBIs are generally less administratively burdensome for distributed generation technologies than conventional PBIs.
} 
bottlenecks. Additional drivers may include reduced utility load growth, ${ }^{3}$ internalization of environmental and energy security attributes of renewable technologies, or the desire to elicit technical and market barriers of renewable energy technologies. In this manner successful rebate programs may reduce technology costs, demonstrate technological feasibility, reveal potential market barriers, and/or increase market penetration. Further, well-designed, well-targeted rebate programs can contribute to a larger market initiation for clean energy projects that can potentially lead - in partnership with other policies - to market transformation.

In relation to energy efficiency rebates, renewable energy rebates are a relatively recent phenomenon. California began using clean energy funds ${ }^{4}$ in 1998 to provide grants and rebates to renewable energy installations in the state (Bolinger 2003). Many states mimicked California, and as of October of 2008, 25 states offered rebate programs ${ }^{5}$ for renewable electricity generating technologies and 38 states offered rebates for renewable energy systems (DSIRE 2008). ${ }^{6}$

The purpose of this paper is to provide a basic overview of how rebate programs impact renewable energy markets and to discuss rebate program trends as they relate to the market transformation process. More specifically, this paper summarizes the effects of renewable energy rebate programs on the basic renewable energy policy drivers, discusses the current status and experience of rebate programs, and discusses the value of rebate programs as market initiators. It also considers ideal applications, design considerations, key elements of a successful program, policy complements, and policy alternatives.

\footnotetext{
${ }^{3}$ Reduced utility load growth allows a utility and the respective ratepayer base to avoid or forestall the high cost of building new power plants and/or energy infrastructure.

${ }^{4}$ Clean energy funds often rely on a small surcharge or price adder placed on consumers' energy bills to fund renewable energy or energy efficiency programs. These programs may be administered at the utility or at a state-wide level.

${ }^{5}$ The 25 rebate programs are utility or state programs; technology coverage varies depending on the utility service area.

${ }^{6}$ Renewable energy systems include electric generating systems as well as solar hot water heaters and geothermal heat pumps. These latter technologies may sometimes be considered energy efficiency technologies; however, DSIRE classifies them as renewable energy technologies.
} 


\section{Rebate Program Prevalence}

Rebate programs have played a significant role in the emergence of distributed generation renewable energy markets and are likely to continue to play a critical role in the deployment and diffusion of renewables.

As of October 2008, the Database of State Incentives for Renewable Energy (DSIRE) had documented 228 renewable energy rebate programs administered by the state or local utilities throughout the United States. ${ }^{7}$ Thirty-eight states have at least one rebate program for at least one renewable energy technology. Of these 38 states:

- 18 offer a state-level rebate program of some form ${ }^{8}$;

- 7 have a rebate program that covers virtually all forms of renewable energy technologies ${ }^{9}$;

- 25 have at least one rebate program that supports photovoltaics (PV);

- 26 have at least one rebate program that supports solar hot water installations;

- 27 have at least one rebate program that supports geothermal heat pumps; and

- 17 have at least one rebate that supports wind power.

As the popularity of rebate programs continues to increase, their impact on renewable energy markets and technologies will spread.

\footnotetext{
${ }^{7}$ Generally, state-level programs apply to the whole state while utility-administered programs typically offer rebates only to those customers within their service territory.

${ }^{8}$ The definition of renewable energy technologies in this report includes PV, wind power, solar water heating, biomass for power generation and heat, and geothermal heat-pumps.

${ }^{9}$ This does not suggest that rebates are available for all renewable technologies for all individuals. It merely states that in a given state, rebate programs are available for at least a portion of the state and enough programs are available that somewhere in the state all renewable technologies are eligible for a rebate of some form.
} 


\section{Overview of Renewable Energy Market Activity with Rebates}

Given the popularity of rebate programs, an assessment of the market activity resulting from rebate program implementation is included here.

It is important to note that individual rebate programs rarely reflect the same incentive level because they are designed and/or implemented differently. ${ }^{10}$ Furthermore, system installations under these programs may qualify for additional state or federal incentives that could also support market growth. ${ }^{11}$ This high-level market review has not evaluated the relative impact of rebates separately from other complementary or supplemental incentives. However, it is worth noting that declines in PV rebate payments in 2006 and 2007 are offset to some extent by the implementation of the federal Investment Tax Credit (ITC). In spite of these caveats, because rebate programs have generally been the primary incentive in the markets reviewed here, this data is believed to be sufficient for providing a sense of the market activity that is possible from state rebate programs.

\section{Solar Photovoltaic}

The most active and consistently successful renewable energy rebate programs often target photovoltaic (PV) technology. Historically, these programs have been a primary driver of market growth in this industry, resulting in thousands of solar power installations.

\section{California}

California is the largest solar market in the United States (Sherwood 2008). At the end of 2007, the market consisted of 279.5 MW of grid-connected PV capacity (Lieberg 2007). California's PV rebate program was first implemented in 1998 when the California Energy Commission (CEC) began offering rebates for up to $\$ 3.00 /$ watt. Initially, the program increased grid-tied PV installations in California from one per month to 30 per month (Bolinger 2002).

Despite plans to reduce rebate values, market and cost trends forced the CEC to increase the rebate from $\$ 3.00 /$ watt to $\$ 4.50 /$ watt in mid 2001 . Around the same time, PV installations also jumped from about 30 per month to 300 a month. However, based on the timing of this dramatic rise, it is possible that the California energy crises in early

\footnotetext{
${ }^{10}$ Even when the dollar value of rebates in two different states appears similar, they are not necessarily comparable. Additional policy or market barriers or incentives along with general retail electricity rates influence rebate values.

${ }^{11}$ The broadest complementary policy for solar installations is the federal Investment Tax Credit (ITC). Implemented in 2006, it allowed a 30\% tax credit up to $\$ 2,000$ for residential installations and increased the commercial ITC from $10 \%$ up to $30 \%$ through 2008 . However, state rebate programs are often $\$ 2,500 / \mathrm{kW}$ up to $\$ 4,500 / \mathrm{kW}$ with systems commonly ranging from $2.5 \mathrm{~kW}$ to $5 \mathrm{~kW}$. Up to this point, state rebate programs have generally dwarfed the value of the federal ITC for residential installations. The single exception here is in Oregon where as of 2007 the state's business and residential energy tax credits for PV are roughly comparable to the Energy Trust of Oregon rebate for residential systems, $\$ 3 /$ watt up to $\$ 6,000$ and are up to $50 \%$ of the cost of commercial systems depending on the year of the installation.
} 
2001 and the implementation of a state tax incentive program ${ }^{12}$ may have also been significant drivers in this ten-fold growth (Bolinger 2002).

The average annual growth of installed units from 1999-2007 has been 119\%; the largest percentage increase in market growth was in 1999 and 2001. Figure 1 shows annual PV market activity by systems installed and allocated rebate values according to the state's Emerging Renewables Program (ERP) Statistics.

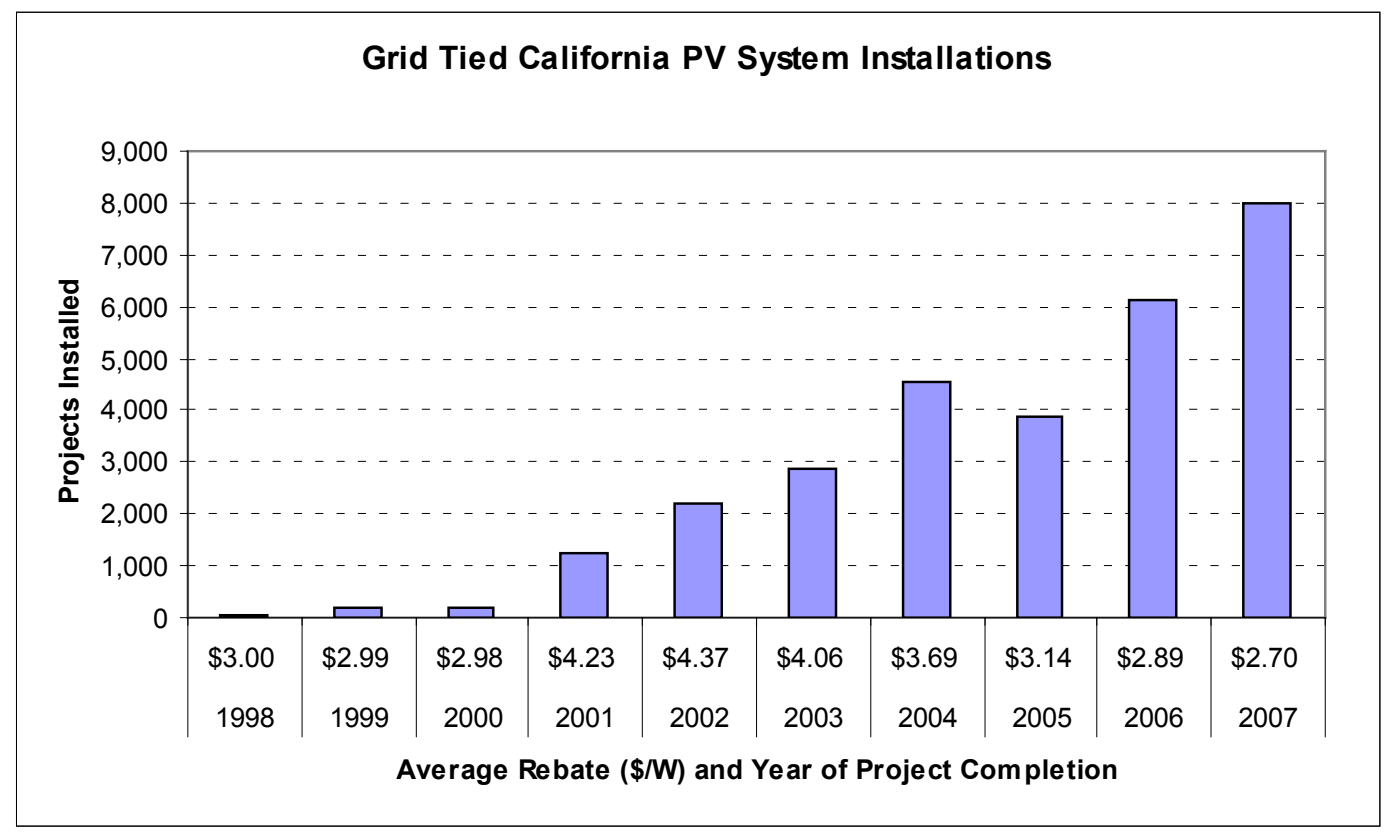

Figure 1. Annual PV market and average rebate paid $(\$ / k W)$ in the grid connected California market

Source: ERP Statistics ${ }^{13}$

\section{New Jersey}

The second largest PV market in the United States is New Jersey, with a total installed PV capacity of more than $62 \mathrm{MW}$ (Sherwood 2008). This growth has been driven by New Jersey's Customer On-site Renewable Energy (CORE) rebate program which began dispersing funds in 2001 . The full rebate value was originally more than $\$ 5.00 /$ watt but it has been scaled down moderately over time. ${ }^{14}$ Despite a slow initial start, the program rapidly expanded and annual installed capacity has increased every year. Overall from 2001 to 2007, growth in annual installations has averaged 200\% (see Figure 2). In fact, the program became so popular that receipt of new PV applications was suspended on

\footnotetext{
${ }^{12}$ California's state tax incentive, in place from 2001 through 2005, provided a $15 \%$ state tax credit for wind and solar systems installed in 2001-2003 and a 7.5\% tax credit for systems installed in 2004-2005.

${ }^{13}$ The average rebate paid is representative of ERP funded projects. However, in 2007, new applications began to be processed under the California Solar Initiative (CSI). While the total systems installed is representative of both ERP and CSI projects for 2007, the average rebate paid in 2007 only reflects rebates paid for ERP projects.

${ }^{14}$ Declining rebate payments in 2006 and 2007 are at least partially offset by the federal ITC.
} 
April 1, 2008, due to limited funds (NJBPU 2008). New Jersey now relies on its solar renewable energy credit (SREC) markets as the primary incentive for new PV systems.

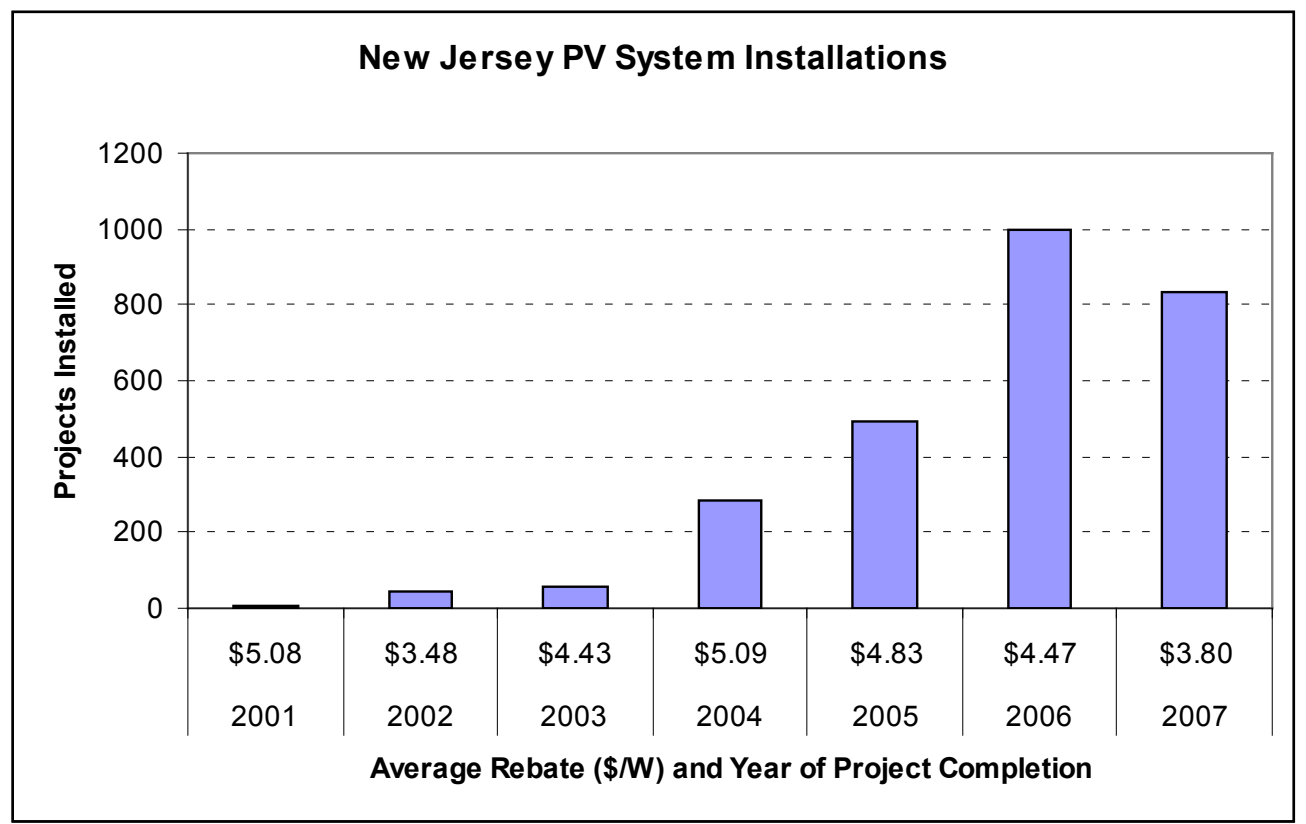

Figure 2. Annual PV installations supported by New Jersey's CORE rebate program Source: New Jersey CORE Program Activity

\section{Colorado}

Although Colorado has much smaller total PV capacity - estimated at 9.7 MW as of June 2008 - the state has observed rapid growth in installed solar capacity as a result of its solar rewards rebate program. Solar rebates allocated in Colorado are similar to those in New Jersey with a program average of $\$ 4.27 /$ watt. Average annual growth in projects installed in Colorado has been $92 \%$, and approved standard rate rebates has grown from 33 per month in 2006 to 100 per month as of June 2008 (see Figure 3) (CDOR 2008). 


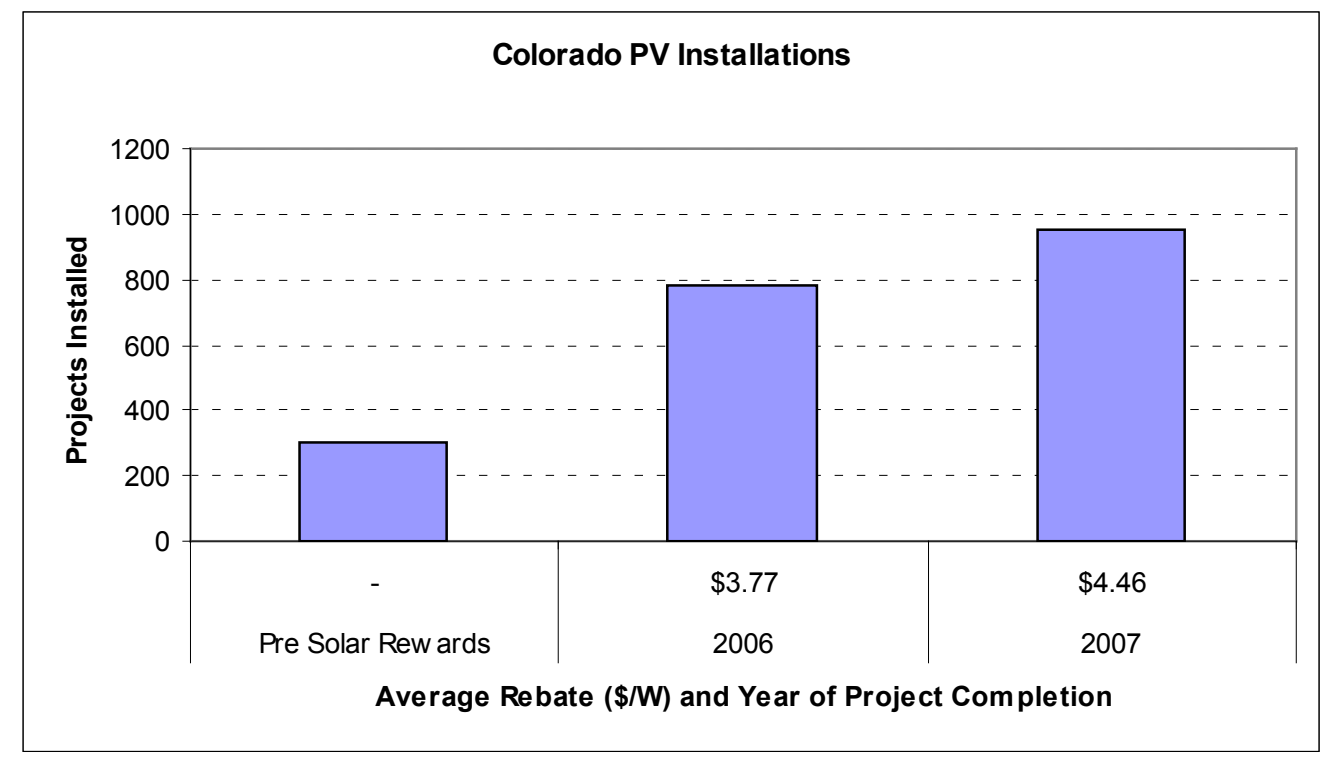

Figure 3. Market impacts by annual PV system installations and rebate value

Source: Colorado Department of Regulatory Agencies.

\section{Oregon}

In Oregon's market, rebates are available to customers of Portland General Electric and Pacific Power through Energy Trust of Oregon (ETO) rebate programs. ${ }^{15}$ From 2003 through 2007, solar system installations grew from 74 to 225 while capacity grew from $197 \mathrm{~kW}$ installed per year to more than $1 \mathrm{MW}$ installed in 2008.

Whereas New Jersey and Colorado initially had very high levels of growth that has tempered, Oregon's ETO program has seen an increase in the annual installation growth rate from $57 \%$ in 2004 to $73 \%$ in 2007 , despite a decline in average rebate value (see Figure 4) (ETO Program Statistics). However, Oregon's dramatically declining ETO rebate value is largely offset by the federal ITC and the state's Residential Energy Tax Credit which currently provides a tax credit of up to $\$ 3 /$ watt, not to exceed $\$ 6,000$ or $50 \%$ of the installed cost (DSIRE 2008).

\footnotetext{
${ }^{15}$ The ETO is responsible for investing system benefits charges collected by the state's two largest investor owned utilities - Portland General Electric and Pacific Power-in energy efficiency measures and emerging renewable energy markets.
} 


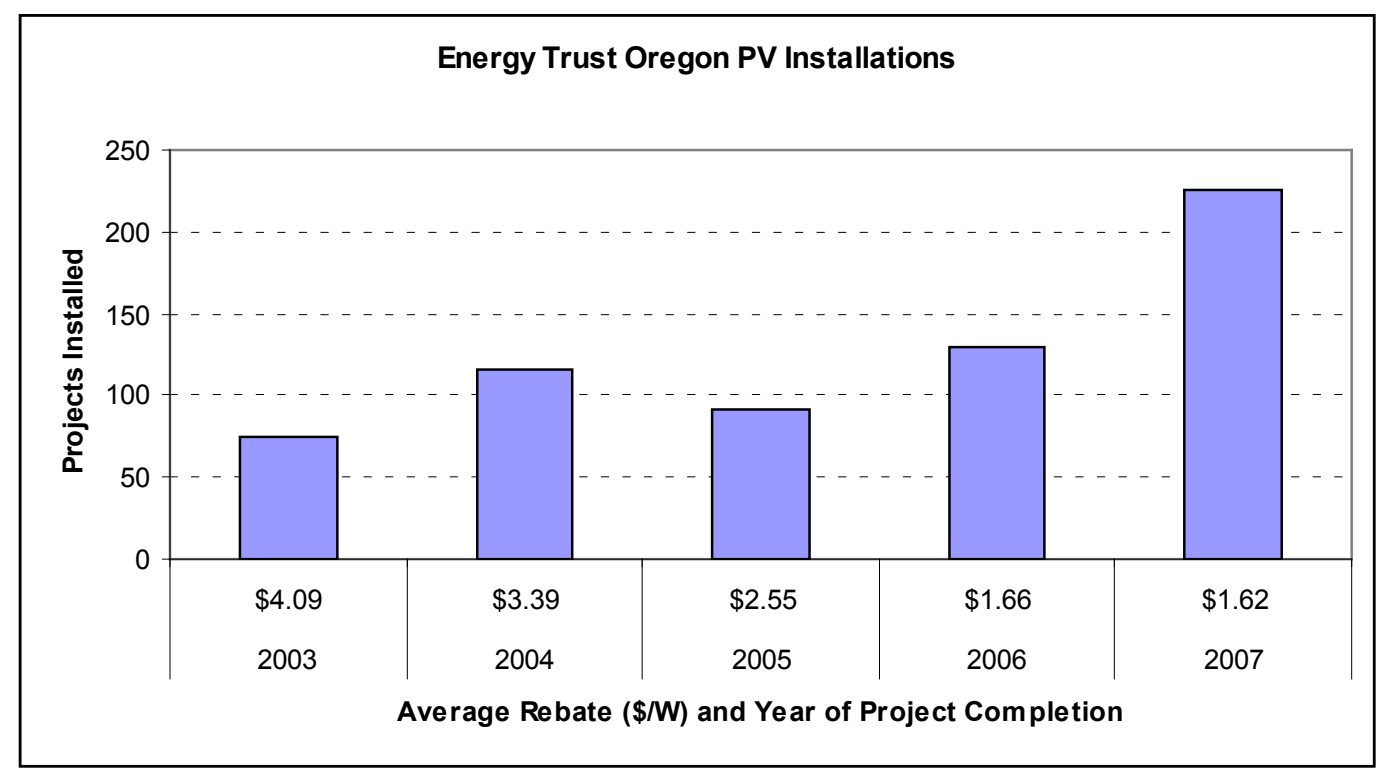

Figure 4. PV market impacts in the commercial and residential sector as a result of ETO rebates

Source: ETO Program Statistics

\section{PV Rebates Conclusions}

The success of prominent state rebate programs in stimulating PV installations is clear; however, it is less clear if these programs have effectively driven down PV technology costs. Some evidence shows that California's installation costs and the balance of plant costs have declined (Wiser 2006). However, PV technology ultimately remains a niche technology out of reach for most potential consumers in the absence of continued rebates or other incentives.

\section{Solar Water Heating}

Solar water heating rebate programs are generally less common than PV rebate programs. However, a handful of rebate programs for solar water heating technologies have been implemented and the Hawaiian Electric Company (HECO) and the ETO - two of the larger programs - are reviewed here.

In 1996, HECO implemented a rebate program to supplement a 35\% state tax credit. HECO's rebate program offered an additional $\$ 750$ incentive to the state's tax credit. Market growth expanded moderately for the first two years of the program but was flat during subsequent years. With the combined rebate and state tax incentive, the average annual growth rate from 1996 through 2005 was 4\%, suggesting only a marginal impact from the incremental incentive increase (Richmond 2007). ${ }^{16}$

\footnotetext{
${ }^{16}$ On a side note, in June of 2008, the Hawaiian Government signed a bill into law that requires all new homes applying for building permits to include a solar hot water system. Exclusions are available for specific conditions. The law goes into effect in 2010.
} 
The ETO currently offers a rebate that averages $\$ 819$ per system for solar water heating installations. This incentive is in addition to the federal ITC and a state tax credit of up to $\$ 1,500$ per system. ${ }^{17}$ Growth in Oregon under these conditions in 2007 was $25 \%$ (ETO Program Statistics).

Given these programmatic results, rebate programs for solar hot water appear to have only a moderate impact on market activity. In addition, it seems unlikely that these rebate programs have reduced production costs for solar hot water technologies or moved the industry toward mass production.

\section{Small Wind Systems}

Another technology that has been the recipient of rebates is small wind systems. The success of small wind rebates has varied between states and programs.

According to this research, California has the most successful small wind rebate program. There, growth in the number of systems installed annually has averaged $41 \%$ since 1998 , with an average rebate value at approximately $45 \%$ of the installed system cost (see Figure 5). ${ }^{18}$ Between 1998 and 2002, installations grew at 56\% annually and the rebate value was approximately $48 \%$. However, growth in California faltered from 2003 through 2005 as the state attempted to scale back the rebate.

After the market collapsed, the rebate was reinstituted at a maximum of $\$ 2.50 /$ watt for systems up to $7.5 \mathrm{~kW}$ in mid $2006 .{ }^{19}$ Since 2006 , rebate levels have remained at that level and market activity has resurged with 2007 installations up 188\% over 2006 (ERP Program Statistics).

The California program is estimated by the American Wind Energy Association (AWEA) to be a major small wind market driver and as such has helped grow the production levels of small wind technologies (AWEA 2008).

\footnotetext{
${ }^{17}$ In this case the federal ITC provides a 30\% tax credit (capped at \$2,000/ system through 2008) to the net installed cost of the system.

${ }^{18}$ This percentage is derived from actual system costs and rebate disbursements in California.

${ }^{19}$ An additional \$1.50/watt was available for capacities in excess of $7.5 \mathrm{~kW}$ and below $30 \mathrm{~kW}$.
} 


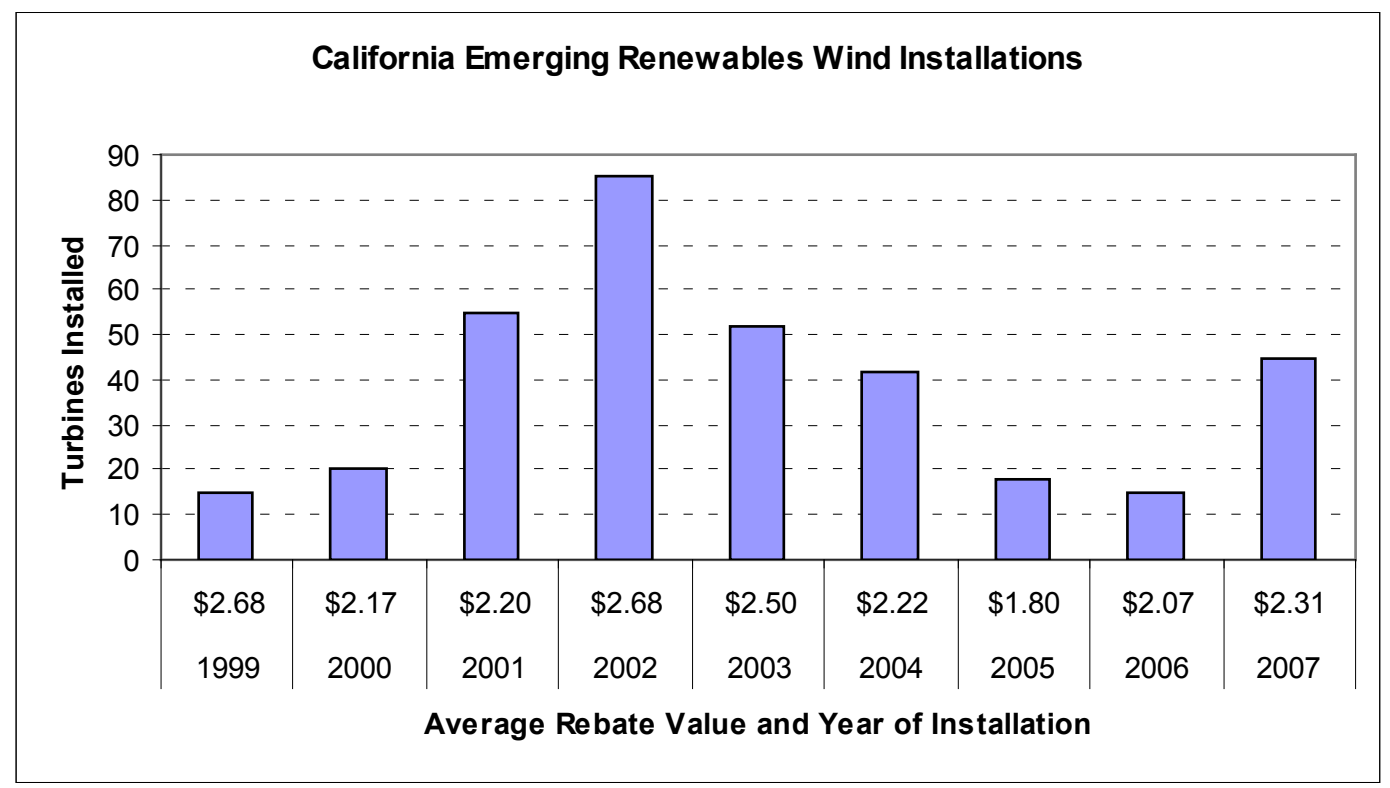

Figure 5. Small wind turbine installations by year and average rebate $(\$ / k W)^{20}$

Source: ERP Program Statistics

Despite California's success, two other small wind incentive programs in New Jersey and Oregon have failed to stimulate notable market growth. Through December 2008, New Jersey offered a rebate through its CORE program for wind systems. The average rebate paid for systems $20 \mathrm{~kW}$ and under during this time was $\$ 3.98 /$ watt. Despite the relatively high rebate value, this program only resulted in five system installations $20 \mathrm{~kW}$ and under through 2007 (NJ CORE Web site). ${ }^{21}$

From 2004 through November 2007, the ETO offered rebates to small wind systems on a case-by-case basis. The average program rebate during this time was $\$ 1.23 /$ watt with a range from $\$ 0.50 /$ watt up to $\$ 8.77 /$ watt. This program resulted in five system installations over the four year period. In November 2007, a new incentive program went into effect that offered up to $\$ 4.50 /$ watt, capped at $\$ 35,000$ for residential systems with an additional $\$ 6,000$ production-based state tax credit available for residential systems. Based on a dramatic rise in applications, demand for the new standardized rebate program has greatly increased; however, only two projects had been approved and completed as of September 2008 (ETO Wind Program Statistics).

Possible explanations for the variable success of small wind rebate programs include wind resource limitations, local zoning requirements, and the lack of a standard rebate provision. The mixed success also suggests small wind rebate programs could benefit from increased market and technical potential analysis prior to program implementation.

${ }^{20}$ As was the case for California's solar PV market, these installations were also supported by a state tax incentive from 2001-2005.

${ }^{21}$ The $20 \mathrm{~kW}$ and under designation is noted due to the fact that one single $2.6 \mathrm{MW}$ installation occurred in 2007. The rebate amount for this specific installation was less than $\$ 1 /$ watt. This single project brings the total CORE wind program average rebate estimate to $\$ 0.74 /$ watt. 


\section{Biomass Power Systems}

Biomass energy technologies have also received rebate incentives. This review considers two example biomass programs that have had moderate success.

Through December 2008, New Jersey's CORE rebate program offered rebates for facilities that generated up to $1 \mathrm{MW}$ of electricity from sustainable biomass resources. Rebates were available at a rate of $\$ 0.15 /$ watt up to $\$ 5.00 /$ watt, depending on the size of the system and state evaluation criteria (NJ CORE Web site). Activity in this market was slightly less than one project per year (see Table 1).

The ETO administers a biopower program that has funded projects since 2005. Funds are dedicated to biomass power generation projects that may sell within Portland General Electric or Pacific Power service territories. However, the ETO program is not a traditional rebate program. Each applying project is evaluated on its specific merits and funds may be allocated up to $100 \%$ of the above-market costs of power production (ETO program Web site).

Biopower rebate program results and market activity for Oregon and New Jersey are summarized in Table 1 (ETO Program Statistics).

Table 1. State Level Biopower Program Results

\begin{tabular}{|c|c|c|c|}
\hline & $\begin{array}{l}\text { Projects } \\
\text { Supported } \\
\text { (annually) }\end{array}$ & $\begin{array}{c}\text { Average Project } \\
\text { Size (kW) }\end{array}$ & $\begin{array}{c}\text { Average } \\
\text { Funding per } \\
\text { project }(\$ / \mathrm{kW})\end{array}$ \\
\hline New Jersey & 0.86 & 386 & $\$ 1,462$ \\
\hline Oregon & 1.00 & 1583 & $\$ 336$ \\
\hline Average & 0.93 & 862 & $\$ 983$ \\
\hline
\end{tabular}

Rebate programs for biopower projects often include the array of biomass powergenerating technologies and fuel sources, including anaerobic methane, agriculture waste, and landfill gas. While this strategy is thought to increase program popularity, it fails to reflect the specificity often necessary to jumpstart a specific technology market. 


\section{Rebate Programs and Market Activity: General Conclusions}

Assuming that rebate programs are primarily in place to initiate new market activity or jump-start emerging industries, their success has been mixed. State rebate programs have provided a major impetus for solar PV installations in all states reviewed here and for small wind installations in California. However, solar hot water rebates and biopower programs, along with certain small wind programs, have not had the same level of success. In addition, rebate programs frequently have the goal of achieving cost reductions at scale, and despite large public expenditures, many residential and commercial-scale technologies remain niche technologies.

Variable success suggests a few conclusions about rebate programs:

- When properly designed, market growth can be dramatic. Proper design requires being technology specific, establishing the most effective rebate amount, minimizing program costs, establishing a standard rebate allocation procedure, and developing a thorough and specific market potential analysis.

- Programs that target technologies that may not be ready for the marketplace are not likely to advance market expansion.

- In cases where well-designed incentives are ineffective at stimulating market growth, resources may be better targeted at non-cost related market barriers like interconnection standards, net-metering, or public awareness.

- At the current level of observed cost reductions from rebate programs, it is unlikely that rebate programs alone will achieve widespread renewable energy deployment.

- Complementary policies that allow renewable energy technologies to internalize their full value may be necessary to ensure the long-term viability of renewable energy technologies. 


\section{Impacts on Renewable Energy Policy Drivers}

Renewable energy rebates often target residential and commercial consumers and comparable distributed-scale energy technologies. In this specific market, rebates are a primary driver of distributed power generation and deployment of renewable energy technologies. For example, solar power rebate programs in California have supported installation growth from approximately one system per month to the point where 111 MW of grid-tied solar power was added in the first nine months of 2008 alone (CSI 2008). However, because rebate programs are often applied to smaller scale emerging technologies with limited or zero market share, the short-term market impacts of successful rebate programs on some high-level renewable energy policy driversincluding economic development, environmental benefits, and energy security —may be limited when compared to the scale of electricity and energy markets at the state or national level. ${ }^{22}$

This portion of the analysis profiles the qualitative and quantitative impacts of renewable energy rebates on high-level energy policy drivers. Table 2 summarizes the qualitative impacts of well-designed and successful rebate programs on the breadth of high-level policy drivers. Table 3 highlights the deployment impacts of rebate programs as a function of market growth rates under solar rebate programs in four different states. Tables 4-6 highlight the quantitative short-term impacts of existing rebate programs on total electricity sales, economic development, and environmental quality.

\footnotetext{
${ }^{22}$ Table 4 shows that when compared with state electricity retail sales, rebate programs rarely constitute more than $1 \%$ of a state's electricity supply.
} 
Table 2. Rebate Program Impacts on High-level Clean Energy Policy Drivers

\begin{tabular}{|c|c|c|c|}
\hline $\begin{array}{c}\text { Overarching } \\
\text { Renewable } \\
\text { Energy } \\
\text { Drivers }\end{array}$ & Potential Policy Goals & $\begin{array}{l}\text { Short- } \\
\text { term } \\
\text { Policy } \\
\text { Impacts }\end{array}$ & Notes \\
\hline Environment & $\begin{array}{l}\text { Clean air benefits (SOx, NOx, mercury, } \\
\text { and particulates) } \\
\text { Greenhouse gas emissions reductions } \\
\text { Reduce water consumption } \\
\text { Reduce water pollution (heat and mercury) } \\
\text { Reduced fuel extraction impacts } \\
\text { Preserve sensitive areas } \\
\text { Protect wildlife/endangered species } \\
\text { Minimize human impacts } \\
\text { Waste stream management (farm, forestry, } \\
\text { municipal wastes) }\end{array}$ & Limited & $\begin{array}{l}\text { Rebate programs can provide a direct source } \\
\text { of clean energy resources to consumers. } \\
\text { However, because of limited market } \\
\text { penetration in the short-term, rebate } \\
\text { programs are not expected to contribute } \\
\text { greatly to broad environmental policy goals. } \\
\text { Rebate programs should be viewed as } \\
\text { market initiators which, when partnered with } \\
\text { complementary policy, can support } \\
\text { environmental goals over the long-term. }\end{array}$ \\
\hline \multirow[t]{3}{*}{$\begin{array}{c}\text { Economic } \\
\text { Development }\end{array}$} & $\begin{array}{l}\text { Job creation } \\
\text { State economic development } \\
\text { Reduce electricity costs } \\
\text { Provide electricity price stability } \\
\text { Revitalize rural areas }\end{array}$ & Limited & \multirow{3}{*}{$\begin{array}{l}\text { Rebate programs are typically targeted at } \\
\text { small emerging markets. This limited scale } \\
\text { often means that the economic benefits from } \\
\text { RE rebates are a small fraction of state's } \\
\text { gross domestic product. However, smaller } \\
\text { RE projects may present prime opportunities } \\
\text { for community owned energy resources. } \\
\text { Rebates may also attract investment by } \\
\text { manufacturers when they are indicative of a } \\
\text { supportive policy environment. }\end{array}$} \\
\hline & Attract new investment & Moderate & \\
\hline & Develop local or community-owned assets & High & \\
\hline \multirow{3}{*}{$\begin{array}{l}\text { Energy } \\
\text { Security }\end{array}$} & $\begin{array}{l}\text { Ensure an abundant energy supply } \\
\text { Ensure an affordable energy supply } \\
\text { Reduce transfer of wealth outside the U.S. } \\
\text { Become a net exporter of energy }\end{array}$ & Limited & \multirow{3}{*}{$\begin{array}{l}\text { In the short-term, rebate programs generally } \\
\text { do not create new large sources of energy } \\
\text { production. However, solar power can } \\
\text { function as a peak demand reducer and } \\
\text { distributed generation-often the target of } \\
\text { rebate programs-may have a positive } \\
\text { impact on system resiliency. Rebate } \\
\text { programs targeted at transportation } \\
\text { technologies are likely to have the greatest } \\
\text { long-term impact on energy security. }\end{array}$} \\
\hline & $\begin{array}{l}\text { Diversify energy resources } \\
\text { Provide peak demand reductions } \\
\text { Increase grid resiliency }\end{array}$ & Moderate & \\
\hline & Encourage distributed energy generation & High & \\
\hline \multirow[b]{3}{*}{$\begin{array}{l}\text { Renewable } \\
\text { Energy (RE) } \\
\text { Deployment }\end{array}$} & $\begin{array}{l}\text { Reduce fossil fuel consumption } \\
\text { Stimulate innovation } \\
\text { Reduce baseload needs }\end{array}$ & Limited & \multirow{3}{*}{$\begin{array}{l}\text { The short-term value of rebate programs is } \\
\text { concentrated in market development and } \\
\text { achieving cost reductions at scale. } \\
\text { Immediate large-scale impacts on other } \\
\text { policy goals are limited. However, without } \\
\text { early stage market development, } \\
\text { technological learning, and cost reductions, } \\
\text { the long-term success of renewable energy is } \\
\text { likely to be reduced. }\end{array}$} \\
\hline & Reduce technical and policy barriers & Moderate & \\
\hline & $\begin{array}{l}\text { Stimulate rapid RE market } \\
\text { expansion/development } \\
\text { Support basic technological advancement } \\
\text { Provide cost reductions at scale } \\
\text { Facilitate learning by doing } \\
\text { Meet renewable portfolio standards/quota } \\
\text { targets } \\
\text { Stimulate early adoption }\end{array}$ & High & \\
\hline
\end{tabular}


Table 2 indicates that the highest impact area of rebate programs is in renewable energy deployment and California's experience noted above clearly supports this characteristic. Furthermore, Table 3 shows the dramatic growth in markets where solar PV rebate programs have been implemented and provides a sense of the magnitude of growth that is possible in rebate markets. ${ }^{23}$ As such, well-designed programs can be a critical component of renewable energy deployment by driving rapid market expansion.

Table 3. State Solar Rebate Program Installed Project Average Annual Growth Rate (AAGR)

\begin{tabular}{|l|c|c|c|c|}
\hline & $\begin{array}{c}\text { Years of } \\
\text { Data }\end{array}$ & $\begin{array}{c}\text { Program } \\
\text { Life AAGR }\end{array}$ & $\begin{array}{c}\text { Average } \\
\text { Rebate \$/kW }\end{array}$ & $\begin{array}{c}\text { Estimated Rebate value } \\
\text { (percent of total cost) }\end{array}$ \\
\hline New Jersey & 7 & $200 \%$ & $\$ 4,457$ & $50 \%$ \\
\hline Colorado & 2.5 & $92 \%$ & $\$ 4,271$ & $47 \%$ \\
\hline Oregon & 5 & $38 \%$ & $\$ 2,660$ & $30 \%$ \\
\hline California & 10 & $119 \%$ & $\$ 3,204$ & $36 \%$ \\
\hline $\begin{array}{l}\text { State Program } \\
\text { Averages }\end{array}$ & & $124 \%$ & $\$ 3,494$ & $39 \%$ \\
\hline
\end{tabular}

Source: State Program Data-additional information is available in the list of references

However, Table 2 also suggests that rebate program impacts on the environment, energy security, and economic development policy goals are limited in the short term. These limitations exist primarily because rebate programs have not significantly altered the energy sector at the state or national scale. This characteristic is somewhat inherent in the rebate mechanism because it typically targets smaller distributed scale technologies, but also because rebate programs are frequently applied to emerging technologies which generally start with little or zero market share.

Table 4, which is designed to quantify the short-term energy security impact of state rebate programs, shows the limited scale and market share of state rebate programs. It also shows that, in general, state rebate programs have not added significantly to the diversity of electricity generating resources in the states reviewed here. As a result, rebate program impacts on energy security are generally limited. Furthermore, as state rebate programs typically target electricity generating technologies, they are unlikely even in the most successful cases to have more than a moderate impact on fossil fuel imports. ${ }^{24}$ To have a higher impact on energy security in the long term, rebates ideally should be targeted at transportation technologies and fuels that reduce petroleum consumption.

\footnotetext{
${ }^{23}$ The term "magnitude of growth" is used in this context because growth in these programs, though predominantly driven by the state rebates, has at times been supported by complementary state and federal policies.

${ }^{24}$ Because renewable electricity offsets natural gas power generation and natural gas imports, moderate impacts are derived.
} 
Table 4. Short-term Energy Security Impact: Estimated Annual Energy Production from Capacity Installed under State Rebate Programs*

\begin{tabular}{|l|r|l|l|l|l|}
\hline & $\begin{array}{l}\text { Solar } \\
\text { Photovoltaic } \\
\text { (kWh) }\end{array}$ & $\begin{array}{l}\text { Small } \\
\text { Wind } \\
\text { (kWh) }\end{array}$ & $\begin{array}{l}\text { Biomass } \\
\text { Power } \\
\text { (kWh) }\end{array}$ & $\begin{array}{l}\text { Solar Hot } \\
\text { Water } \\
\text { (kWh) }\end{array}$ & $\begin{array}{l}\text { Percentage of } \\
\text { Total State } \\
\text { Electricity Retail } \\
\text { Sales** }\end{array}$ \\
\hline California & $203,018,168$ & $2,737,062$ & & & $0.08 \%$ \\
\hline New Jersey*** & $70,738,489$ & $3,503,124$ & $16,237,536$ & & $0.11 \%$ \\
\hline Colorado & $14,533,103$ & & & & $0.03 \%$ \\
\hline Oregon & $3,772,144$ & 118,917 & $44,367,648$ & $3,164,347$ & $0.11 \%$ \\
\hline Hawaii & & & & $162,579,985$ & $1.54 \%$ \\
\hline Wisconsin & & & & $1,512,372$ & $0.00 \%$ \\
\hline
\end{tabular}

${ }^{*}$ Energy production is based on average industry capacity factors and the installed capacity from state specific rebate programs. Capacity data include the total capacity installed by rebate program participants.

** Total State Retail Sales are 2006 data from the Energy Information Administration (www.eia.doe.gov).

*** $2,625 \mathrm{~kW}$ of wind capacity is from one project in 2007.

The small market share that rebate programs have established for distributed renewable energy technologies also suggests that rebate programs alone are not likely to singlehandedly drive the emergence of a new clean energy economic sector. Nevertheless, rebate programs do support a small number of jobs and can contribute hundreds of millions of dollars in economic output in the short term (see Table 5). In addition, when rebate programs are structured to provide long-term market support and stability, they may encourage investment in local businesses and create a competitive advantage in attracting new renewable energy manufacturing facilities. Attracting a large-scale investment such as a new manufacturing facility can dramatically increase the economic development benefits of renewable energy technologies. Thus, a rebate program can aid in the creation of a vibrant local industry over the long term.

Table 5. Short-term Economic Development: Modeled Solar Industry Economic Development Impacts from Capacity Installed under State Rebate Programs

\begin{tabular}{|l|c|c|c|}
\hline & $\begin{array}{l}\text { Solar Industry } \\
\text { Installation and } \\
\text { Production Jobs } \\
\text { (Short-term) }\end{array}$ & $\begin{array}{l}\text { Solar Industry } \\
\text { Maintenance } \\
\text { Jobs (Long- } \\
\text { term) }\end{array}$ & $\begin{array}{l}\text { Solar Industry } \\
\text { Economic } \\
\text { Output }\end{array}$ \\
\hline California & 1,636 & 136 & $\$ 378,580,079$ \\
\hline New Jersey & 570 & 48 & $\$ 131,910,277$ \\
\hline Colorado & 117 & 10 & $\$ 27,100,743$ \\
\hline Oregon & 30 & 3 & $\$ 7,034,141$ \\
\hline
\end{tabular}

Note: Total economic development impacts typically include direct (industry specific), indirect (supporting industries), and induced (benefits from increased economic activity generally) impacts. The above values represent only the direct economic development impacts captured primarily by the solar industry. Short-term jobs include construction and manufacturing jobs and are defined as full-time jobs for one year. Long-term jobs continue for as long as the installations continue producing electricity. Modeled values are derived from Grover (2006) and vetted against a pre-release version of NREL's JEDI Solar PV Model (www.nrel.gov/analysis/jedi/) as well as previous analysis by Navigant Consulting (2008). Values are based on the installed capacity of state specific rebate program participants. 
In contrast to economic development impacts which tend to result indirectly from renewable energy development and manufacturing investment, renewable energy rebate programs contribute directly to environmental policy goals. The estimated direct environmental impacts from PV programs in California, New Jersey, Colorado, and Oregon are quantified in Table 6. However, because the market share of renewable technologies installed under these programs is still very small relative to the broader energy sector, renewable energy rebate programs are not likely to fundamentally alter the energy sector's overhaul emissions profile.

Table 6. Environmental Impacts: Estimated Emissions Reductions from Capacity Installed under State Rebate Programs

\begin{tabular}{|l|c|c|c|c|}
\hline & California & New Jersey & Colorado & Oregon \\
\hline Carbon Dioxide (tons) & 159,246 & 55,487 & 11,400 & 2,959 \\
\hline Nitrogen Oxides (tons) & 225 & 78 & 16 & 4 \\
\hline Sulfur Dioxide (tons) & 623 & 217 & 45 & 12 \\
\hline \multicolumn{5}{|l|}{} \\
\hline Mercury (Ibs) & 4.93 & 1.72 & 0.35 & 0.09 \\
\hline Methane (Ibs) & 3,631 & 1,265 & 260 & 67 \\
\hline Nitrous Oxide (Ibs) & 2,027 & 706 & 145 & 38 \\
\hline
\end{tabular}

Note: Environmental impacts are estimated based on the energy production estimates outlined in Table 4. Capacity values are derived from state program data and include the total capacity installed by rebate program participants. Rebate program installations are assumed to offset non-baseload power generation as defined in eGRID 20071.0 (http://www.epa.gov/cleanenergy/energy-resources/egrid/index.html).

Ultimately, successful rebate programs are used as policy mechanisms that increase market penetration, drive technologies to production at scale, and provide opportunities for learning by doing. By initiating renewable technology markets and facilitating deployment of new technologies, in partnership with complementary policies, rebate programs can be a critical first step toward a secure, clean, and prosperous energy future. 


\section{Challenges Associated with Rebate Programs}

Rebate programs have proven to be successful at initiating rapid market expansion in specific contexts. However, rebate programs should be designed to fit at a specific point in the technology development and deployment cycle. If initiated late in the deployment cycle, they can become very expensive if required to support a large and rapidly growing industry. Similarly, if initiated too early, they may be underutilized or ineffective at reducing technology costs. As such, there are some specific challenges associated with rebate programs.

\section{Fiscal}

The primary fiscal challenge is assessing the proper rebate amount. Such a task may appear relatively straightforward. However, a variety of context-specific policy and market conditions can affect the market landscape for a given renewable energy technology. A well-designed rebate program will provide a rebate sufficient to encourage market growth, but not so large that the program cannot meet demand.

Electricity price and additional state, local, and federal incentives should be reviewed carefully when considering the correct rebate amount as these variables can greatly affect how economic a specific renewable energy system is within a given market. In addition, the rate of market growth being sought, as well as the size of the market to support, should be considered. Furthermore, reaching specific economic price levels can trigger exponential growth and care must be taken so the market does not grow so fast that program funding is exhausted prematurely (Paidipati 2008). ${ }^{25}$

Establishing a viable rebate amount also requires considering the expected technology cost reductions over time, how to proceed if those cost reductions are not realized, and how often rebate values should be reevaluated. These considerations are critical to ensuring market stability which in turn encourages reliable project financing and investment in renewable energy infrastructure and manufacturing facilities.

\section{Freeridership}

Freeridership is defined as the allocation of rebates to individuals who are likely to purchase a renewable energy technology without a rebate. In any case where market activity is moderate or high prior to rebate program implementation, freeridership can dramatically increase the cost of new rebate programs and reduce their market impacts. In addition, a rebate program that is only funded at a level that meets or marginally exceeds

\footnotetext{
${ }^{25}$ New Jersey's CORE solar PV rebate program suspended receipt of new applications in 2008 due to insufficient funds. Exponential market growth often occurs when moving from low penetration $(<10 \%)$ to very high levels of penetration $(>50 \%)$. Over this range of market penetration, the technology diffusion curve becomes very sensitive to small changes in market economics (Paidipati 2008). This suggests that technological viability is likely to be threshold sensitive, and rebate program administrators must be sensitive to these market conditions.
} 
market demand in the absence of the incentive is likely to result in the provision of rebates primarily to freeriders. ${ }^{26}$

Even where funds for rebates greatly exceed existing market demand, freeriders can have a significant and detrimental impact on state rebate programs. Ultimately, high growth markets are not viable candidates for rebate programs due to freeridership. In markets that are undergoing moderate growth in the absence of rebate programs, market analysis becomes increasingly important to evaluate the tradeoff between market growth and the cost of funding freeriders.

\section{System Performance}

Many rebate programs are capacity- or cost-based (i.e., there is a specific up-front rebate per watt or per dollar spent to develop the facility). However, these rebates may not provide any incentives for a system owner to ensure maximum production from their system. As a result, some rebate programs have shifted to performance-based or expected performance-based incentives. The former provides incentive payments over time for energy generation rather than as an up-front capacity incentive. Unfortunately, performance-based incentives for distributed generation may result in increased administrative and technical costs, and do not directly address the high up-front costs of renewable energy systems. As a result, expected performance-based incentives are designed to capture the value of both up-front rebates and performance-based payments. Expected performance-based incentives adjust the full up-front incentive payment in accordance with expected performance.

\section{Administrative Burden and Costs}

Challenges for rebate programs also include minimizing overhead and administrative costs. Very small rebate programs, like biomass programs where only one or a few rebates are provided, may be prone to high overhead costs. In addition, non-standard rebate programs where funds are provided based on individual project finances and expected profitability can potentially result in high administrative costs. ${ }^{27}$ Administrative cost reductions may result from a streamlined application and permitting process as well as increasing the standardization of rebate allocations.

\section{Non-cost Barriers}

In addition to economic and cost conditions, there are non-cost related market barriers that can affect the outcome of a rebate program. Two primary examples that must be considered when evaluating the potential outcome of a rebate program are net-metering and interconnection rules or standards. In addition, local zoning requirements, program publicity, public desire for clean energy, public concern over energy independence or the

\footnotetext{
${ }^{26}$ Indiana's geothermal heat pump rebate program is a perfect case example. Rough market estimates place the Indiana market at approximately 1,000 systems per year (Albertson 2008). However, under the rebate program, only 300 rebates were provided (Cummings 2008). Though quantitative analysis has not been performed, this disproportion suggests that the bulk of the state rebates were simply consumed by individuals who were likely to purchase a geothermal heat pump without the rebates.

${ }^{27}$ In Oregon, one large-scale biomass installation actually received no specific rebate funds but still resulted in high costs to the states clean energy fund due too high levels of assistance from ETO staff.
} 
environment, general public awareness, and disposable income all affect the outcome of a given program and should not be underestimated when planning rebate programs.

\section{Policy Duration and Flexibility}

The final challenge for rebate programs is how to move forward when markets and technology costs do not follow the expected trajectories. Many policymakers and constituents view rebate programs as a temporary boost to emerging markets. Common thinking is that as the industry grows, economies of scale can be realized throughout the supply chain and manufacturing process and technology cost reductions will result. To fall within funding authorizations, programs are often designed so that rebate values can be gradually reduced over time to reflect the reduced costs that are expected to accrue as a given industry or technology moves toward the mainstream.

However, up to this point, rebate program administrators and policymakers have had only limited success in forecasting the timing and extent of technology cost reductions. In California, history shows that rebate values have actually been increased to sustain market growth despite scheduled reductions. However, technology cost increases may result from factors beyond the control of program administrators or technology producers. Volatile commodity prices, market growth that results in supply chain bottlenecks, or inflationary pressures can generally all drive up prices even if production and installation is becoming more efficient. In these cases, evaluating program success and developing a plan for continued program implementation can be difficult. 


\section{Ideal Conditions and Applications}

The nature of rebate programs often means that the greatest short-term impacts are on renewable energy deployment. As such, they often serve a relatively narrow and specific purpose, so knowing when and where to apply them is critical. This section highlights the ideal conditions and applications for renewable energy rebate programs.

\section{The Right Technology, the Right Market}

Many rebate programs apply broadly to an array of renewable energy technologies. However, this approach may not recognize the nuance of specific technology markets and the timing-sensitive nature of technology viability. Specific renewable energy technologies typically occupy different niches within energy markets. Ideally, rebate programs can target the optimal technology based on its specific merits, broader market characteristics, and the available resources. ${ }^{28}$

In addition, rebates should go to technologies that are ready for widespread application and are not expected to undergo major technological breakthroughs in the near term. Rebate programs are best applied to technologies that only foresee long-term marginal improvements from research and development (R\&D) but have significant cost savings that might be achieved through mass production, learning by doing, and economies of scale. Ideally, specific technology cost reductions are identified and measurable.

\section{Small Markets with Low or Zero Growth}

Rebates are often best applied to technologies with small or non-existent markets and low or zero growth. This ensures low freeridership and optimizes government investment. For example, offering a rebate on compact fluorescent light bulbs (CFL) in a market where there is high penetration would result in an expensive program since rebates go to all purchasers and many consumers are willing to purchase CFLs without a rebate. Instead, rebates can be lower cost to governments when applied to technologies with large potential, but little current market share, such as residential $\mathrm{PV}^{29}$

\section{Moving from Prototype to Mass Production}

Rebate programs are best applied to technologies that are ready to make the leap from a few prototypes to mass production. Markets that are capable of moderate growth in the absence of a rebate program, or markets that have already achieved production on a moderate scale, tend not to be good rebate program candidates due to freeridership, high program costs, and a more limited probability of achieving cost reductions from changes in production scale.

\footnotetext{
${ }^{28}$ A good programmatic fit is California's solar PV rebates. Relatively high electricity rates and an abundant solar resource have led to sustained growth in the solar PV market over the full 10 years of the program. New Jersey's CORE rebate program for small wind technology is a poor fit as the program does not match a given energy market with the proper resource.

${ }^{29}$ Given the recent extension and modifications to federal renewable energy incentives, this criterion suggests that states may benefit from evaluating the market impact of current federal incentives before implementing a new state rebate program as some renewable energy technologies may be able to achieve moderate levels of growth in specific markets with the federal incentives alone. At a minimum, the increased value of federal incentives may allow rebate programs reduce the necessary rebate to meet a specific level of growth.
} 


\section{Under-utilized Workforce}

If a specific market has an under-utilized workforce that could easily engage in renewable energy industries, policymakers may consider implementing a rebate program to demonstrate a supportive policy environment. Evidence suggests that manufacturers may prefer localities that embrace renewable energy and existing policy as one means of communicating renewable energy acceptance and support.

\section{High-value Markets with Supporting Technical Policy}

Ideal applications for renewable energy rebate programs include consumer markets with high priced retail energy alternatives, a populace that is both knowledgeable and engaged in energy and environmental issues, and a market where technical and non-cost barriers have already been removed. Consumers who are unaware or uninterested in renewable energy technologies are not likely to pursue any new energy technology. In addition, if technical or policy barriers prevent consumers from capturing the full value of renewable energy through net-metering, time of use rates, and renewable energy credit sales, public resources may be better spent eliminating these barriers before spending money on rebate programs. 


\section{Key Elements of a Successful Program}

While elements of a successful rebate program vary depending on one's definition of success, the basic definition of success is taking an emerging technology from the prototype stage to mass production. There are few key pieces that must be present to ensure rebate program success, including:

- An appreciation of the market-initiating attributes and scale limitations of the rebate programs.

- The ability to address non-cost barriers including public awareness, net-metering, and interconnection standards. This may involve implementing a suite of policies in conjunction with a given rebate program.

- Targeting the right technology at the right time. Technologies that make good candidates for rebate programs should be at the proper point in the technology development and diffusion cycle. This is likely to require careful technology and market analysis.

- A clear knowledge of and consideration for existing state, local, or federal incentives, as well as their impacts on current market activity and expected market activity under the new rebate program.

- Targeting technologies with foreseeable concrete cost reductions at scale and a methodology for addressing unexpected changes in cost. ${ }^{30}$

- Establishing the proper rebate amount based on existing market trends, the cost of alternatives, and the size of market that is desired. ${ }^{31}$

- Providing a clear and specific mechanism for reevaluation and adjustment of rebate values based on changes in market dynamics during the life of the rebate program.

- A level of funding that is able to exceed existing market demand and sustain growth so that market volatility resulting from changes in rebate availability and funding are minimized.

\footnotetext{
${ }^{30}$ In some markets, supply and demand pressures coupled with increasing commodity prices have actually pushed prices up rather than down. Without cost reductions, a rebate program may simply support an industry that is dependent on government support for viability.

${ }^{31}$ Rebate values that are too large may overheat markets and exhaust funding prematurely. Conversely, rebate values that are too low may not stimulate market demand.
} 


\section{Policy Complements and Alternatives}

Renewable energy rebate programs occupy a specific niche in the portfolio of policies that may advance renewable energy into the mainstream of the United States. As such, there are policy complements and policy alternatives to renewable energy rebate programs.

\section{Tax Credits}

Tax credits are probably the most common alternative for moving technologies from the prototype stage to production at scale. The most comparable form of tax credit is the federal ITC. In principle, tax credits function similarly to rebate programs; however, there are a few critical differences. First, tax credits may not be collected until an individual files their tax returns in the year following the purchase. In addition, a tax credit requires a tax liability for the consumer to capitalize on the value of the incentive. Finally, a tax credit does not require an actual funding appropriation because the tax credit is merely a reduction in tax base. As a result, the fiscal impact is less direct for a tax credit than a rebate program.

\section{Feed-in Tariffs}

One policy that could function as either an alternative or complement to enhance renewable energy economics and expand renewable energy markets is feed-in tariffs (FIT) or production-based incentives (PBI). FITs have been very successful at driving renewable energy expansion in Germany but have only received limited application in the renewable energy sector of the United States. Typically, a FIT or PBI provides a specific payment amount to renewable energy generators based on the amount of energy produced from a given system. Payments may be at a fixed price or adjustable based on existing market rates. Unlike rebates, these programs do not reduce the up-front cost barrier but they may provide longer-term industry stability. As a production based incentive, FITs also provide incentives for maximum system production and may streamline administrative costs by providing a simple payment based on power generation.

\section{Net-metering}

Net-metering best functions as a policy complement. Net-metering allows users of distributed generation technologies to sell the excess power they generate back to the utility at the retail rate and allows them to draw power from the utility when their own generation is insufficient. Without net-metering, individuals may receive no benefit for excess power generation above real-time consumptions levels or they may be compensated with wholesale power rates. Net-metering can be an important economic benefit for high cost renewable energy systems and may encourage larger system installations.

\section{Time-of-Use Rates}

Time-of-use rates also function as policy complements. These rate structures allow certain technologies, like PV, to maximize economic value from renewable energy generation by providing market price signals for net-metered systems. Because maximum daily PV power generation often correlates well with peak electricity demand periods, time-of-use rates allow net-metered PV to benefit from peak retail electricity rates. 
Higher prices for excess power, during peak electricity demand periods, increases the benefit that accrues from net-metered PV systems.

\section{REC Compliance Markets}

Creating a compliance-based renewable energy credit (REC) $)^{32}$ market is an alternative policy mechanism that could be used to incentivize distributed generation renewable energy development. This approach, sometimes employed under a renewable portfolio standard, establishes a guaranteed market for RECs up to the specific capacity or generation level that is mandated by the legislature. Income from sales of RECs into this market is then used to offset the cost associated with renewable energy installations. These markets can be designed to be technology specific; targeting residential and small commercial distributed technologies is likely to require such a technology specific designation.

The solar REC compliance market approach is now New Jersey's primary incentive for $\mathrm{PV}$. The primary attribute of this approach is that it is a market-based mechanism that encourages renewable energy development. However, because RECs are tradable market goods, prices can vary, sometimes dramatically, with supply and demand and this mechanism may not provide the stability necessary to efficiently build renewable energy markets. In addition, this type of incentive may be more complex for home-owners and distributed generation technologies to participate in. As a result, a REC compliance market may be better suited for mature renewable energy.

\section{Public Infrastructure Investment}

Public infrastructure investment involves the installation of renewable energy technologies on public buildings and property and off sets conventional power needs of public infrastructure. This approach ensures that no single segment of the population benefits at a greater level than another and allows for relatively low cost support for renewable energy technologies. However, this policy is not likely to have the market expansion impacts that a well designed rebate program may have because it does not leverage any private funding. Public infrastructure investment targeted at renewable energy may be more efficiently targeted at earlier stage R\&D or pilot projects.

\footnotetext{
${ }^{32}$ RECs represent the environmental attributes of the renewable power generation and can be sold separately from the physical electricity. For more information on RECs and green power markets, see http://apps3.eere.energy.gov/greenpower/index.shtml.
} 


\section{Conclusion}

Renewable energy rebates are a policy mechanism designed to reduce cost barriers to renewable energy technologies and encourage consumer uptake. However, rebate programs are ideally established with the specific purpose of short-term market initiation or rapidly expanding small markets that are undergoing low or zero annual growth.

Rebates function best when applied to market-ready technologies that are prepared to move a technology from the prototype stage to mass production with the explicit purpose of reducing technology costs, demonstrating technological feasibility, revealing potential market barriers, and increasing market penetration. Rebate programs may function poorly when context-specific market factors are not considered or when the precise rebate amount is not tailored to existing market and policy conditions.

Rebate programs may be most effective when well designed and implemented as one component in a suite of policies. Under this scenario, rebates can be applied to jumpstart or rapidly expand a specific renewable energy technology while additional policy measures may be put in place to capture the full value of renewable energy resources and ensure that institutional barriers, technical barriers, and public awareness are also addressed. 


\section{References}

1. Albertson, P. September 2008. Personal Communication. Waterfurnace Incorporated.

2. American Wind Energy Association (AWEA) (2008). AWEA Small Wind Turbine Global Market Study. AWEA. http://www.awea.org/smallwind/. Accessed October 24, 2008.

3. Barbose, G.; Wiser, R.; Bolinger, M. (2006). Designing PV Incentive Programs to Promote Performance: A Review of Current Practice. Berkeley, CA. http://eetd.lbl.gov/ea/ems/cases/. Accessed October 23, 2008.

4. Biopower Program Statistics. Energy Trust Oregon. Unpublished Data Obtained by Request from the Energy Trust of Oregon. http://www.energytrust.org/

5. Bolinger, M.; Wiser, R. (2003). Learning by Doing: The Evolution of State Support for Photovoltaics. LBNL-52398. Berkeley, CA. Lawrence Berkeley National Laboratory

6. Bolinger, M.; Wiser, R. (2002). The Use of Capital-and Performance-Based Buy-Down Programs for PV in California, Pennsylvania, and Massachusetts. Berkeley, CA. Lawrence Berkeley National Laboratory http://eetd.lbl.gov/ea/ems/cases/. Accessed October 23, 2008.

7. Colorado Department of Regulatory Agencies (CDOR). Public Utilities Commission. The Renewable Energy Standard Adjustment. Xcel Energy Solar Rewards Program. Archive of Monthly Reporting June 2006-July 2008. http://www.dora.state.co.us/puc/rulemaking/Amendment37/Amendment37.htm. Accessed October 24, 2008.

8. Cummings, P. (2008). Indiana Residential Geothermal Heat Pump Rebate Program Review. Indiana Office of Energy and Defense Development. http://www.in.gov/oed/files/GHPProgramreport.pdf. Accessed October 24, 2008.

9. Database of State Incentives for Renewable Energy (DSIRE). http://www.dsireusa.org/ Accessed December 16, 2008.

10. Emerging Renewables Program Statistics. Obtained by Request from the California Energy Commission. http://www.energy.ca.gov/renewables/emerging_renewables/index.html. Accessed October 24, 2008.

11. Emissions and Generation Integrated Database (eGRID) 2007 Version 1.0. U.S. Environmental Protection Agency. http://www.epa.gov/cleanenergy/energyresources/egrid/index.html Accessed December 17, 2008.

12. Energy Information Administration (EIA) (2006). State Electricity Profiles. http://www.eia.doe.gov/fuelelectric.html. Accessed December 16, 2008.

13. Energy Trust of Oregon. Program Web site. http://www.energytrust.org/. Accessed October 27, 2008.

14. Grover, S. (2007). Energy Economic and Environmental Benefits of the Solar America Initiative. Prepared by ECONorthwest Portland, OR for the National Renewable Energy Laboratory. Golden, CO http://www.nrel.gov/docs/fy07osti/41998.pdf Accessed December 16, 2008. 
15. Jobs and Economic Development Impacts (JEDI) Model. Draft Solar Photovoltaic Model. National Renewable Energy Laboratory. www.nrel.gov/analysis/jedi/

16. Leiberg, T.; Lee, J. (2007). Grid Connected PV Capacity Installed in California (Data through 12/31.07). http://www.gosolarcalifornia.ca.gov/news/statistics/index.html. Accessed October 24, 2008.

17. Navigant Consulting (2008). Economic Impacts of Extending Federal Solar Tax Credits. Prepared for the Solar Energy Research and Education Foundation. http://www.seia.org/galleries/pdf/Navigant\%20Consulting\%20Report\%209.15.08 .pdf. Accessed December 16, 2008.

18. New Jersey Board of Public Utilities (NJBPU) (2008). Docket No. EO07100773.

19. Paidipati, J.; Frantzis, L.; Sawyer, H.; Kurrasch, A. (2008). Rooftop Photovoltaics Market Penetration Scenarios. Prepared by Navigant Consulting. National Renewable Energy Laboratory NREL/SR-581-42306. http://www.nrel.gov/docs/fy08osti/42306.pdf. Accessed October 27, 2008.

20. Richmond, R. (2007). Solar Water Heating Program Overview. Presentation Prepared by Hawaiian Electric Company. U.S. DOE Solar Hot Water Market Expansion Workshop. http://www1.eere.energy.gov/solar/ush2o/shw_market_expansion_workshop 010 7.html. Accessed October 24, 2008.

21. Sherwood, L. (2008) U.S. Solar Market Trends 2007. Interstate Renewable Energy Council. http://irecusa.org/. Accessed October 24, 2008.

22. Solar Electric Program Statistics. Energy Trust Oregon. Unpublished Data Obtained by Request from the Energy Trust of Oregon. http://www.energytrust.org/

23. Solar Hot Water Program Statistics. Energy Trust Oregon. Unpublished Data Obtained by Request from the Energy Trust of Oregon. http://www.energytrust.org/

24. State of New Jersey Clean Energy Web site. Renewable Energy CORE Activity. http://www.njcleanenergy.com/renewable-energy/program-updates/coreactivity/core-activity. Accessed October 27, 2008.

25. Wind Program Statistics. Energy Trust Oregon. Unpublished Data Obtained by Request from the Energy Trust of Oregon. http://www.energytrust.org/

26. Wiser, R.; Bolinger, M.; Cappers, P.; Margolis, R. Letting the Sun Shine on Solar Costs: An Empirical Investigation of Photovoltaic Cost Trends in California. LBNL-59282. Lawrence Berkeley National Laboratory. Berkeley, CA. http://eetd.lbl.gov/ea/emp/reports/59282.pdf Accessed December 16, 2008. 


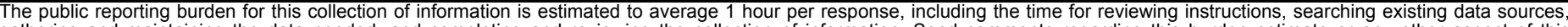

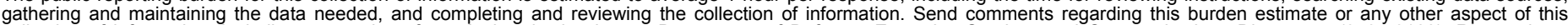

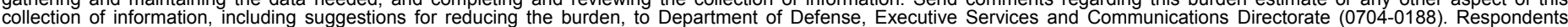

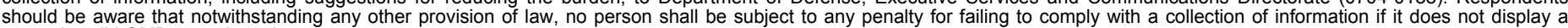

should be aware that notwithstanding

PLEASE DO NOT RETURN YOUR FORM TO THE ABOVE ORGANIZATION.

\begin{tabular}{l|l|l|l} 
1. REPORT DATE (DD-MM-YYYY) & 2. REPORT TYPE & 3. DATES COVERED (FrOm - TO)
\end{tabular} March 2009

Technical Report

4. TITLE AND SUBTITLE

State Clean Energy Practices: Renewable Energy Rebates 5a. CONTRACT NUMBER

DE-AC36-08-GO28308

5b. GRANT NUMBER

5c. PROGRAM ELEMENT NUMBER

5d. PROJECT NUMBER

NREL/TP-6A2-45039

5e. TASK NUMBER

IGST.8300

5f. WORK UNIT NUMBER
7. PERFORMING ORGANIZATION NAME(S) AND ADDRESS(ES)

National Renewable Energy Laboratory

1617 Cole Blvd.

Golden, CO 80401-3393
8. PERFORMING ORGANIZATION REPORT NUMBER

NREL/TP-6A2-45039

9. SPONSORING/MONITORING AGENCY NAME(S) AND ADDRESS(ES)

10. SPONSOR/MONITOR'S ACRONYM(S) NREL

11. SPONSORING/MONITORING AGENCY REPORT NUMBER

12. DISTRIBUTION AVAILABILITY STATEMENT

National Technical Information Service

U.S. Department of Commerce

5285 Port Royal Road

Springfield, VA 22161

13. SUPPLEMENTARY NOTES

14. ABSTRACT (Maximum 200 Words)

This report functions as a primer for renewable energy rebate programs. It highlights the impacts of specific renewable energy rebate programs on renewable energy markets around the country, as well as rebate program impacts on overarching energy policy drivers. It also discusses lessons learned, challenges, ideal applications, keys to success, and complementary and alternative policies. Results indicate that rebate programs can have a strong deployment impact on emerging renewable energy markets. This report focuses on renewable energy rebate programs, which are being analyzed as part of the State Clean Energy Policies Analysis (SCEPA) project. SCEPA is being used to quantify the impacts of existing state policies, and to identify crucial policy attributes and their potential applicability to other states.

15. SUBJECT TERMS

Renewable energy rebate programs; renewable energy markets; deployment impact; State Clean Energy Policies Analysis project; SCEPA; United States; NREL; Eric Lantz; Elizabeth Doris.

\begin{tabular}{|l|l|l|l|l|}
\hline $\begin{array}{l}\text { 16. SECURITY CLASSIFICATION OF: } \\
\begin{array}{c}\text { a. REPORT } \\
\text { Unclassified }\end{array}\end{array}$ & $\begin{array}{c}\text { b. ABSTRACT } \\
\text { Unclassified }\end{array}$ & $\begin{array}{l}\text { c. THIS PAGE } \\
\text { Unclassified }\end{array}$ & $\begin{array}{c}\text { LF ABSTRACT } \\
\text { UL }\end{array}$ & $\begin{array}{c}\text { 18. } \\
\text { OUMBER PAGES } \\
\text { OF PAON }\end{array}$ \\
\hline
\end{tabular}

19b. TELEPHONE NUMBER (Include area code) 